\title{
Influence of physiological and health quality on the vigor of cucumber seeds
}

\section{Influência da qualidade fisiológica e sanitária no vigor de sementes de pepino}

\author{
Vanessa Nogueira Soares ${ }^{1 *}$ (D), Francisco Amaral Villela' (D), Aline Klug Radke' (D), \\ Hélen Claudine Saliba Rodrigues ${ }^{1}$ (D), Vanessa Pinto Gonçalves ${ }^{1}$ (D), Géri Eduardo Meneghello ${ }^{1}$
}

\begin{abstract}
The physiological performance of seeds is related to their physiological quality and seed vigor, while their health quality may interfere with germination and early seedling establishment in the field due to the interaction of microorganisms associated with seeds. The study aimed to evaluate the physiological performance and health quality of cucumber seeds and to verify the relationship between these attributes. The physiological quality of cucumber seeds was evaluated by standard germination tests, first count of germination, controlled deterioration test, electrical conductivity test, seedling emergence, emergence speed index, and traditional accelerated aging and aging modified with saline for 48, 72, and $96 \mathrm{~h}$. The health quality of cucumber seed lots was evaluated by blotter test. Stratification of cucumber seed lots by seedling emergence was similar to seedling emergence by controlled deterioration test, first count of germination, and electrical conductivity results. The cucumber seed lots evaluated showed high germination rates; however, lots 1 and 3 had a better performance in vigor tests than lots 2 and 4 . Fungi detected in the blotter test were Alternaria sp., Aspergillus sp., Cladosporium sp., and Penicillium sp. Seed lots 2 and 4 had low vigor evaluated by seedling emergence and controlled deterioration, and showed a higher incidence of Penicillium sp. in the evaluation of health quality of seeds. The incidence of Penicillium sp. may negatively affect the vigor of cucumber seeds evaluated by seedling emergence and by controlled deterioration test.
\end{abstract}

KEYWORDS: Cucumis sativus; Penicillium sp.; physiological potential; seed health.
RESUMO: O desempenho fisiológico de sementes diz respeito à sua qualidade fisiológica e vigor, enquanto a qualidade sanitária pode interferir na germinação e estabelecimento inicial de plântulas no campo devido à interaçáo dos micro-organismos associados às sementes. O trabalho teve por objetivo avaliar o desempenho fisiológico e a qualidade sanitária de sementes de pepino e verificar a relação entre esses atributos. A qualidade fisiológica de sementes de pepino foi avaliada pelos testes de germinação, primeira contagem de germinação, deterioração controlada, condutividade elétrica, emergência de plântulas, índice de velocidade de emergência e envelhecimento acelerado tradicional e modificado com solução salina por 48, 72 e 96 horas. A qualidade sanitária das sementes foi avaliada pelo método do papel-filtro. A estratificaçáo de lotes de sementes de pepino ocorreu de maneira similar à emergência de plântulas pelos testes de deterioração controlada, primeira contagem da germinação e condutividade elétrica. Os lotes de sementes de pepino avaliados apresentaram alto percentual de germinaçáo; no entanto, os lotes 1 e 3 apresentaram melhor desempenho nos testes de vigor que os lotes 2 e 4 . Os fungos detectados no teste do papel-filtro foram Alternaria sp., Aspergillus sp., Cladosporium sp. e Penicillium sp. Os lotes 2 e 4 de menor vigor avaliados pelos testes de emergência de plântulas e de deterioração controlada foram os mesmos que apresentaram maior incidência de Penicillium sp. na avaliação da qualidade sanitária das sementes. A incidência de Penicillium sp. pode influenciar negativamente o vigor de sementes de pepino avaliado pela emergência de plântulas pelo teste de deterioração controlada.

PALAVRAS-CHAVE: Cucumis sativus; Penicillium sp.; potencial fisiológico; saúde de sementes. 


\section{INTRODUCTION}

The physiological and health quality of seeds are fundamental factors for the establishment of an adequate plant stand in the field. This information is even more important for vegetable seeds (LIMA; MARCOS FILHO, 2011) such as cucumber seeds (Cucumis sativus L.), which requires special care to ensure physiological and phytosanitary performance due to its commercial value and its form of marketing.

One of the limiting factors for the success of vegetable species has been the difficulty of obtaining seeds capable of providing the establishment of a culture with an ideal population and with uniform and vigorous seedlings (ALVES et al., 2012).

Physiological potential is determined by seed vigor, environmental conditions, and crop management at all stages of production and post-harvest. The use of vigor tests is frequently practiced by seed companies; however, there is no standardized test for evaluating the vigor of cucumber seeds.

The physiological performance of seeds is related to their physiological quality and vigor, while their health quality may interfere with the germination and initial establishment of seedlings in the field due to the interaction of microorganisms associated with the seeds (FARRAG; MOHARAM, 2012; NÓIA et al., 2014). The incidence of microorganisms in seeds, regardless of their transmissibility, can affect vigor, longevity, and yield.

The presence of fungi that cause disease, rotting, or contamination can result in a decrease in germination and poorer development of seedlings in the early stages (AVINASH; RAVISHANKAR RAI, 2013).

As seeds with low vigor and/or damage to their structures are predisposed to the more severe action of fungi, it may reflect negatively in their physiological performance (SOARES et al., 2016). Consequently, the aim of this study was to evaluate the physiological and health quality of cucumber seeds and to evaluate the influence of fungi associated with seeds in germination and early seedling performance of cucumber.

\section{MATERIALS AND METHODS}

\section{Plant materials}

This study was carried out at the Laboratory of Seed Analysis and in the greenhouse of Universidade Federal de Pelotas. Four untreated cucumber (C. sativus) seed lots of the cultivar Wisconsin were used and submitted to the following tests:

Moisture content: conducted in an oven with forcedair circulation at $105 \pm 3^{\circ} \mathrm{C}$ for $24 \mathrm{~h}$, in accordance with the Brazilian rules for seed analysis (BRASIL, 2009), using two samples of $4.5 \mathrm{~g}$ of seeds for each lot. Results were expressed as mean percentage weight loss per lot.

The cucumber seed lots were produced according to the production standard of the seed company. However, they may have had different physical, physiological, and health quality. The seed lot commercial numbers are lot 1 , lot 2 , lot 3 , and lot 4 .

\section{Evaluation of physiological performance}

Standard germination test: four subsamples of 50 seeds were used, and the test was performed on paper towels. Evaluations were conducted at 4 and 8 days after sowing, and the results were expressed as the percentage of normal seedlings, according to ISTA (2012).

First count of germination (FCG): performed under the same conditions as the germination test and assessed 4 days after sowing, following the recommendations of ISTA (2012).

Electrical conductivity (EC): assessed by the mass method with four replicates of 50 seeds of pure seed portions per seed lot. The seeds were weighed and soaked in $200-\mathrm{mL}$ plastic cups containing $75 \mathrm{~mL}$ of deionized water. The readings were taken $24 \mathrm{~h}$ after soaking at $25^{\circ} \mathrm{C}$. The conductivity value provided by the device Digimed 32 was expressed in $\mathrm{mS} \mathrm{cm}{ }^{-1} \mathrm{~g}^{-1}$ per seed.

Controlled deterioration $(\mathrm{CD})$ : the seed moisture content was adjusted to $20 \%$ using the wet atmosphere method. For that purpose, 5-g samples of seeds from each lot were distributed in a single layer on a stainless steel mesh inside transparent plastic boxes $(11 \times 11 \times 3.5 \mathrm{~cm})$ which contained $40 \mathrm{~mL}$ of deionized water. The boxes were closed and kept in a chamber at $20^{\circ} \mathrm{C}$, and seeds were weighed periodically until they reached the weight corresponding to the pre-established moisture content. The seed moisture content was adjusted according to the equation (RUTZKE et al., 2008): $\mathrm{X} \mathrm{mL}$ water $=(\mathrm{g}$ seed $) \times(\mathrm{MCf}-\mathrm{MCi} / 1+\mathrm{MCi})$ in which $\mathrm{MCf}=$ desired final moisture concentration and $\mathrm{MCi}=$ initial moisture concentration. The tubes were sealed with Parafilm to prevent moisture evaporation and incubated at $5^{\circ} \mathrm{C}$ for $72 \mathrm{~h}$ to allow the moisture to equilibrate among the seeds. The $\mathrm{CD}$ test was performed at $40^{\circ} \mathrm{C}$ for $48 \mathrm{~h}$. After this period, the samples were kept at ambient temperature for $30 \mathrm{~min}$. The seeds were then subjected to the germination test, according to the methodology described above, with evaluations on the fourth day after sowing.

Accelerated aging (AA) traditional test: a total of 200 seeds (four replicates of 50 seeds) per seed lot were distributed over an aluminum screen placed inside a plastic box (Gerbox ) containing $40 \mathrm{~mL}$ of distilled water, maintained at $41^{\circ} \mathrm{C}$ for 48,72 , and $96 \mathrm{~h}$. After this period, the seeds were allowed to germinate following the methodology used in the standard germination test described above. The percentage of normal seedlings was assessed on the fourth day after 
sowing. The moisture content of the seed was assessed before and after the AA test.

Accelerated aging with saline solution (AASS) test: conducted in a similar way to the AA test, except that the bottom of each plastic box (individual compartment) received $40 \mathrm{~mL}$ of a saturated $\mathrm{NaCl}$ solution as a replacement for water. This solution had the proportion of $40 \mathrm{~g} \mathrm{NaCl}$ $100 \mathrm{~mL}^{-1}$ water, thus establishing an environment of $76 \%$ relative humidity.

Seedling emergence (SE): cucumber seeds were spread at a depth of $2 \mathrm{~cm}$ in trays containing washed and screened sand. Evaluation was performed at 14 days after sowing, by counting the number of seedlings and determining the SE rate.

Emergence speed index (ESI): performed under the same conditions as the SE test; the number of seedlings emerging in each tray was counted daily. Data from the assessments were applied to the formula proposed by MAGUIRE (1962) to get $\mathrm{ESI}: \mathrm{ESI}=\mathrm{E} 1 / \mathrm{N} 1+\mathrm{E} 2 / \mathrm{N} 2+\ldots \mathrm{En} / \mathrm{Nn}$, in which $\mathrm{E} 1$, $\mathrm{E} 2, \ldots, \mathrm{En}=$ the number of normal seedlings counted at the first, second, and last counts; N1, N2, .., Nn = the number of days from sowing to first, second, and last counts.

\section{Evaluation of seed health quality}

Blotter test: 400 seeds were plated in Gerbox ${ }^{\circledR}$ boxes containing well water-soaked blotters (filter papers) and incubated for 7 days at $22^{\circ} \mathrm{C}$ under 12 -h alternating cycles of light and darkness according to the blotter-test method (BRASIL, 2009). Identification of fungi was based on the way they grow on seeds, their "habit characters", and on the morphological characteristics of fruiting bodies and spores/conidia observed under a compound microscope.

\section{Experimental design and statistical analysis}

The experimental design was a completely randomized layout with five replicates. Data expressed as percentages were subject to the following expression: $\arcsin \left(\sqrt{x}_{\mathrm{x}} \div 100\right)$, except for seed health data, which were subject to the expression $(\sqrt{ } x+0.5)$; analysis of variance (Anova) was performed for all data. In the statistical procedure, Anova was performed separately for each test. The means of the lots were compared using Tukey's test $(\mathrm{p}<0.05)$ and Pearson's correlation coefficient $(\mathrm{p}<0.05$ and $\mathrm{p}<0.01$ ); analysis was done using the Winstat 1.0 statistical package (MACHADO; CONCEIÇÃO, 2003). It used four lots and five replicates for each test.

\section{RESULTS AND DISCUSSION}

The cucumber seeds presented a high degree of germination in all lots; there was no difference in the percentage germination of the cucumber lots evaluated (Table 1). No abnormal seedlings were observed in any of the four lots in the germination test; lot 2 had the highest occurrence of dead seeds at $6 \%$. Determination of the physiological quality of seeds is only consistent if this information is complemented by evaluation of vigor, which allows detection of more subtle differences between lots with similar germination, providing an estimate of the seed performance after sowing in the field and/or during storage. The demand for and interest in vigor tests for internal quality control from seed companies are increasing. Thus, the information provided by the germination test can be complemented, obtaining more sensitive tools for the ranking of lots and for reducing the risks arising from the commercialization of low-quality seed lots (KIKUTI; MARCOS FILHO, 2012).

In the CD test, lot 1 had the highest percentage of germination after the stress period, presenting a physiological performance superior to those of lots 2 and 4, and similar to that of lot 3 (Table 1). Lot 4 showed the lowest percentage of germination $(83 \%)$ in the CD test, similar to that of lot 2 (85\%), despite having a higher percentage $(99 \%)$ in the germination test than lot 2 (94\%) (Table 1). As in the germination test, lot 2 had the highest incidence of dead seeds in the CD test, while the other lots did not differ significantly between them. KRZYZANOWSKI et al. (1999) reported that the $\mathrm{CD}$ test allows differentiation of seed lots that are

Table 1. Normal seedlings, abnormal seedlings, and dead seeds (results for germination and controlled deterioration tests of cucumber seeds.

\begin{tabular}{|c|c|c|c|c|c|c|}
\hline \multirow{2}{*}{ Lot } & \multicolumn{3}{|c|}{ Germination (\%) } & \multicolumn{3}{|c|}{ Controlled deterioration (\%) } \\
\hline & NS & AS & DS & NS & AS & DS \\
\hline 1 & $100 \pm 0.10 a$ & $\mathrm{O} \pm \mathrm{Oa}$ & $\mathrm{O} \pm \mathrm{Oa}$ & $90 \pm 1.50 a$ & $9 \pm 1.16 a b$ & $1 \pm 0.40 \mathrm{a}$ \\
\hline 2 & $94 \pm 0.35 b$ & $0 \pm 0.12 a$ & $6 \pm 0.37 c$ & $85 \pm 1.46 b c$ & $8 \pm 0.8 b$ & $7 \pm 0.66 c$ \\
\hline 3 & $99 \pm 0.24 a$ & $0 \pm 0 \mathrm{a}$ & $2 \pm 0.25 b$ & $90 \pm 0.80 a$ & $8 \pm 1.10 b$ & $2 \pm 0.37 a$ \\
\hline 4 & $99 \pm 0.20 a$ & $0 \pm 0.12 a$ & $2 \pm 0 b$ & $83 \pm 1.50 c$ & $13 \pm 1.50 a$ & $4 \pm 0.49 a b$ \\
\hline
\end{tabular}

NS: normal seedlings; AS: abnormal seedlings; DS: dead seeds; means \pm SE followed by the same letter in a column do not differ according to Tukey's test at $5 \%$ probability. 
at different stages of deterioration but have similar germination percentages. According to the CD test, lots 1 and 3 did not differ in vigor, but scored higher than lot 4, evidencing the importance of vigor tests, especially in seeds of high commercial value, such as those of vegetables.

For SE, the lots were classified into three vigor levels, with lots 1 and 3 of the highest vigor with SE of 99 and $98 \%$, respectively. Lot 4 , with $94 \%$ SE, was ranked as medium vigor, and lot 2 with $90 \% \mathrm{SE}$ as lowest vigor (Table 2). The SE test is used as a reference for other vigor tests because according to SOUZA et al. (2013), vigor represents the energy a seed has for rapid and uniform germination and adequate establishment of seedlings under varying environmental conditions. By analyzing the results of the $\mathrm{SE}$ test, it was possible to detect differences in vigor in lots of cucumber seeds with similar germination. The results of the SE test made it possible to verify the inferiority of lots 2 and 4 in relation to lots 1 and 3, as observed in the CD test. Based on SE results, MALONE et al. (2008) recommended the AA test for mogango, and BOLIGON et al. (2010) recommended the germination test at sub-optimal temperature for pumpkin seeds. For radish and coriander, VIEIRA et al. (2013) concluded that the AA test is efficient in sorting seed lots based on SE results.

In the FCG and EC tests, cucumber lots were also stratified at three levels, in which lot 3 was of the highest vigor, lots 1 and 4 of medium vigor, and lot 2 of lower vigor. In the process of deterioration, germination speed decays before the percentage of germination reduces. According to ALMEIDA et al. (2010), the FCG test can be used as an indication of vigor, because as seed deterioration progresses, the germination speed is reduced. The EC test provides information about the integrity of the cell membrane system based on the determination of EC in seed imbibition solution (KRZYZANOWSKI et al., 1999). Damage and/or disorganization of these membranes are generally associated with the process of deterioration and, consequently, the loss of seed vigor.

ESI was not efficient in separating lots, compared to the other tests. According to the ESI results, lot 1 was more vigorous, followed by lot 2 which had the lowest performance in the other vigor tests. Lot 4, classified as having high or medium vigor in the other tests, obtained the worst result for the ESI test. These results indicate that this variable is not consistent to evaluate the vigor of cucumber seeds.

The germination test, performed under favorable conditions, is not sufficient to predict seed performance under sowing conditions which are unfavorable due to low temperature, deep seeding, or other abiotic stress, both in direct seeding in the field and in the production of seedlings in a nursery. Therefore, RADKE et al. (2014) emphasized the importance of performing vigor tests to verify differences in batch quality that the germination test cannot detect.

SE showed significant correlation with germination results $(r=0.6927)$, first germination count $(r=0.7043)$, and EC (- 0.7447) (Table 3). BRAZ; ROSSETTO (2009) verified that the emergence of sunflower seedlings in the field correlates with the vigor, demonstrating comparable trends in variation, serving as an aid to obtaining information to make decisions regarding the selection of lots.

The variables CD and ESI did not correlate with the other variables (Table 3). However, there was a positive and significant correlation between germination and FCG, and a negative and significant correlation between germination and EC and between FCG and EC.

Table 2. Seedling emergence, first count of germination, electrical conductivity, and emergence speed index of cucumber seeds.

\begin{tabular}{lcccc} 
Lot & SE (\%) & FCG (\%) & EC $\left(\mu \mathbf{~ c m}^{-1} \mathbf{g}^{-1}\right)$ & ESI \\
\hline 1 & $99 \pm 0.45 a$ & $90 \pm 0.73 b$ & $18.67 \pm 2.33 \mathrm{~b}$ & $32.82 \pm 0.61 \mathrm{a}$ \\
\hline 2 & $90 \pm 0.98 \mathrm{c}$ & $78 \pm 0.56 \mathrm{c}$ & $6.47 \pm 0.99 \mathrm{c}$ & $28.83 \pm 0.38 \mathrm{~b}$ \\
\hline 3 & $98 \pm 0.68 \mathrm{a}$ & $96 \pm 0.25 \mathrm{a}$ & $9.40 \pm 0.51 \mathrm{a}$ & $24.73 \pm 0.19 \mathrm{c}$ \\
\hline 4 & $94 \pm 1.30 \mathrm{~b}$ & $91 \pm 1.12 \mathrm{~b}$ & $22.97 \pm 1.16 \mathrm{~b}$ & $22.05 \pm 0.67 \mathrm{~d}$ \\
\hline
\end{tabular}

SE: seedling emergence; FCG: first count of germination; EC: electrical conductivity; ESI: emergence speed index; means \pm SE followed by the same letter in a column do not differ according to Tukey's test at $5 \%$ probability.

Table 3. Pearson linear correlation coefficients ( $r$ ) for tests evaluating the physiological quality of cucumber seed lots.

\begin{tabular}{lccccc} 
Variable & G & FCG & CD & ESI & EC \\
SE & $0.6927^{*}$ & $0.7043^{*}$ & $0.6424^{\mathrm{ns}}$ & $0.3177^{\mathrm{ns}}$ & $-0.7447^{*}$ \\
\hline G & & $0.6991^{*}$ & $0.3922^{\mathrm{ns}}$ & $0.0777^{\mathrm{ns}}$ & $-0.7523^{*}$ \\
\hline FCG & & & $0.4404^{\mathrm{ns}}$ & $-0.3089^{\mathrm{ns}}$ & $-0.9342^{*}$ \\
\hline CD & & & $0.4322^{\mathrm{ns}}$ & $-0.4153^{\mathrm{ns}}$ \\
\hline ESI & & & & $0.2034^{\mathrm{ns}}$ \\
\hline
\end{tabular}

*Significant at $1 \%$ probability; ns: not significant; SE: seedling emergence; G: germination; FCG: first count of germination; CD: controlled deterioration: ESI: emergence speed index; EC: electrical conductivity. 
The traditional and modified AA tests at $41^{\circ} \mathrm{C}$ in the three periods evaluated were not efficient in classifying cucumber seed lots (Table 4). These results are in disagreement with those of TORRES (2005) who recommended the traditional AA test at $41^{\circ} \mathrm{C}$ for 72 or $96 \mathrm{~h}$ to evaluate cucumber seed vigor.

We found that the results of the AASS test were less drastic, and not sensitive in detecting differences in vigor between lots. The use of $\mathrm{NaCl}$ salt solution in carrying out the AA test reduces the speed and intensity of water absorption by the seeds, resulting in a less intense deterioration and more uniform results. These results are in disagreement with those of TORRES (2005) who reported that the use of $\mathrm{NaCl}$ during the AA test does not affect the identification of cucumber seed lots with different levels of physiological quality.

$\mathrm{AA}$ and CD tests have been used successfully to distinguish seed lots by vigor level and to predict $\mathrm{SE}$ in the field for various crops. However, the environment for conducting these tests needs to be determined for each species under study (MAVI; DEMIR, 2007).

The combination of temperature and exposure factors in the AA test for cucumber seeds may be appropriate for a given set of lots but may not be for another. Shorter periods of AA may not be efficient for differentiation of lots with high physiological potential, while very long periods may be drastic for lots with low physiological potential. Therefore, the adjustment of an efficient methodology to evaluate seed vigor is not an easy task, since it is necessary, among other things, to evaluate a large number of lots of different cultivars (LIMA; MARCOS FILHO, 2011).
The initial water content of the lots (Table 5) ranged from 6.8 to $7.4 \%$, which is within the limit of variation suggested by the literature for performing tests that evaluate physiological performance, among them the AA test (TEKRONY, 2003). After conducting the traditional AA tests with $\mathrm{NaCl}$ solution, the water content in the seeds presented variation of less than two percentage points, which is within the tolerable limit suggested by MARCOS FILHO (2015). This author recommends looking for differences smaller than two percentage points between lots, indicating that there is uniformity in the test conditions, which contributes to acquisition of consistent results (Table 5). It is worth mentioning that the use of saturated saline solution markedly reduced water absorption by seeds when they did not reach a water content of $10 \%$.

After the CD test, little variation in water content occurred between lots. The procedure was carried out correctly, obtaining values very close to those sought. During the $\mathrm{CD}$ test, it is necessary to take into account the difference in water content of the lots, since differences of one percentage point may influence the percentage of germination after the stress period (TEKRONY, 2003).

The CD test ranked lots similarly to the SE test. Thus, the $\mathrm{CD}$ test proved to be a faster and more practical alternative to obtain information about cucumber seed vigor, especially for estimating seed longevity in storage and seedling performance in the establishment stage in the field. This test has been used to detect differences in the vigor of various vegetable seed lots because it is a relatively simple test, requiring no sophisticated knowledge or significant investment and presenting no marked

Table 4. Germination (\%) of cucumber seeds after three periods of traditional accelerated aging and with saline solution.

\begin{tabular}{|c|c|c|c|c|c|c|}
\hline \multirow{2}{*}{ Lot } & \multicolumn{3}{|c|}{ AA } & \multicolumn{3}{|c|}{ AASS } \\
\hline & $48 h$ & $72 \mathrm{~h}$ & $96 \mathrm{~h}$ & $48 h$ & $72 \mathrm{~h}$ & $96 \mathrm{~h}$ \\
\hline 11 & $91 \pm 1.38 a$ & $92 \pm 0.87 a$ & $91 \pm 1.40 a$ & $97 \pm 1.09 a$ & $95 \pm 0.66 a$ & $95 \pm 1.07 a$ \\
\hline 22 & $89 \pm 1.11 \mathrm{a}$ & $92 \pm 0.75 a$ & $93 \pm 0.58 a$ & $96 \pm 0.81 a$ & $95 \pm 1.08 a$ & $95 \pm 0.97 a$ \\
\hline 33 & $91 \pm 1.39 a$ & $90 \pm 0.86 a$ & $90 \pm 1.88 a$ & $97 \pm 0.93 a$ & $95 \pm 0.60 a$ & $93 \pm 0.40 a$ \\
\hline 44 & $88 \pm 2.09 a$ & $90 \pm 1.86 a$ & $91 \pm 1.91 a$ & $96 \pm 1.39 a$ & $93 \pm 1.50 a$ & $96 \pm 0.93 a$ \\
\hline
\end{tabular}

AA: accelerated aging; AASS: accelerated aging with saline solution; means \pm SE followed by the same letter in a column do not differ according to Tukey's test at $5 \%$ probability.

Table 5. Initial moisture content, moisture content after accelerated aging traditional, moisture content after accelerated aging with saline solution, and moisture content with controlled deterioration tests of cucumber seeds.

\begin{tabular}{|c|c|c|c|c|c|c|c|c|}
\hline \multirow{2}{*}{ Lot } & \multicolumn{4}{|c|}{ MC AA } & \multicolumn{3}{|c|}{ MC AASS } & \multirow{2}{*}{ MC DC } \\
\hline & $M C$ & $48 h$ & $72 \mathrm{~h}$ & $96 \mathrm{~h}$ & $48 h$ & $72 \mathrm{~h}$ & $96 \mathrm{~h}$ & \\
\hline 1 & 6.8 & 25.2 & 27.0 & 27.4 & 7.9 & 9.1 & 8.9 & 19.9 \\
\hline 2 & 7.1 & 25.6 & 27.3 & 27.8 & 8.3 & 9.0 & 9.2 & 20.1 \\
\hline 3 & 7.4 & 26.2 & 28.4 & 29.0 & 8.6 & 9.5 & 9.3 & 20.2 \\
\hline 4 & 7.3 & 26.9 & 28.8 & 28.4 & 8.4 & 9.2 & 9.4 & 19.8 \\
\hline
\end{tabular}

MC: moisture content; MC AA: moisture content after accelerated aging traditional; MC AASS: moisture content after accelerated aging with saline solution; MC CD: moisture content with controlled deterioration. 
difficulties for standardization (GOULART; TILLMANN, 2007), with uniform humidity until the end of the test. These results agree with those observed by LIMA; MARCOS FILHO (2011) who stated that the CD test is efficient for evaluating the vigor of cucumber seeds, allowing them to be separated by vigor level.

In the analysis of the health quality of the seeds, the fungi Alternaria sp., Aspergillus sp., Cladosporium sp., and Penicillium sp. were detected (Table 6). There was no significant difference between the lots in the incidence of Alternaria sp., Aspergillus sp., or Cladosporium sp. However, there was a difference in the incidence of Penicillium sp. which was higher in lots 2 and 4 than in lots 1 and 3 (Table 6). It is important to note that lots 2 and 4 showed poorer performance than the others in SE and CD tests. Most fungi of the genera Aspergillus and Penicillium are classified as storage fungi, being able to survive at low humidity and capable of being present as contaminants or as dormant mycelium inside seeds. Among the damage caused by storage fungi, loss of germination capacity due to seed invasion during storage is the most drastic.

The fungus species Alternaria (A. alternata f. cucurbitae) and Cladosporium (C. cucumerinum) are responsible for necrotic and foliar patches in Cucurbitaceae, respectively (AVINASH; RAVISHANKAR RAI, 2013; NAYYAR et al., 2014). The fungus C. cucumerinum, the causal agent of scab in Cucurbitaceae, also occurs in pumpkin, melon, and watermelon plants. It can cause lesions on leaves, petioles, stems, and fruits, but causes more severe damage in cucumber plants.

The correlation analysis between the variables that evaluated the physiological quality and health quality of seeds showed a significant correlation between the incidence of Aspergillus sp., Cladosporium sp. and Penicillium sp. and the variables of physiological quality (Table 7). The incidence of Aspergillus sp. correlated negatively with FCG $(r=-0.4452)$ and normal seedlings in the CD test $(\mathrm{r}=-0.5075)$, and positively with dead seeds in the CD test $(r=0.5243)$; however, the correlation values were between 0.40 and 0.60 (Table 7).

SE $(r=-0.6551)$, FCG $(r=-0.4821)$, and normal seedlings in the $C D$ test $(r=-0.5075)$ showed a significant negative correlation with the incidence of Cladosporium sp. (Table 7). There was a significant positive correlation of the percentage of dead seeds in the CD test and of variable EC with the incidence of this microorganism (Table 7).

Penicillium sp. showed a high negative correlation with SE $(r=-0.8069)$. The incidence of this fungus also showed significant correlation with germination $(r=-0.5892)$, FCG $(\mathrm{r}=-0.6443)$, abnormal seedlings in the germination test $(r=0.4663)$, dead seeds in the germination test $(r=0.4707)$, normal seedlings in the CD test $(r=-0.5653)$, dead seeds in the $\mathrm{CD}$ test $(\mathrm{r}=0.7009)$, and $\mathrm{EC}(\mathrm{r}=0.6647)$ (Table 7).

Table 6. Fungal incidence (\%) in cucumber seed lots.

\begin{tabular}{lcccc} 
Lot & Alternaria sp. & Aspergillus sp. & Cladosporium sp. & Penicillium sp. \\
\hline 1 & $0.0 \pm \mathrm{Oa}$ & $6.4 \pm 5.66 \mathrm{a}$ & $0.4 \pm 0.24 \mathrm{a}$ & $0.0 \pm 0 \mathrm{~b}$ \\
\hline 2 & $0.4 \pm 0.24 \mathrm{a}$ & $19.0 \pm 10.27 \mathrm{a}$ & $3.2 \pm 1.02 \mathrm{a}$ & $26.4 \pm 4.99 \mathrm{a}$ \\
\hline 3 & $5.0 \pm 5.0 \mathrm{a}$ & $2.2 \pm 0.49 \mathrm{a}$ & $0.0 \pm 0 \mathrm{a}$ & $0.6 \pm 0.40 \mathrm{~b}$ \\
\hline 4 & $3.4 \pm 3.16 \mathrm{a}$ & $14.8 \pm 3.8 \mathrm{a}$ & $4.4 \pm 2.93 \mathrm{a}$ & $24.4 \pm 9.93 \mathrm{a}$ \\
\hline
\end{tabular}

Means \pm SE within a column followed by the same letter do not differ according to Tukey’s test at $5 \%$ probability.

Table 7. Pearson correlation coefficient $(r)$ between fungal incidence and seed physiological quality variables in cucumber seed lots.

\begin{tabular}{lcccc} 
Variable & Alternaria sp. & Aspergillus sp. & Cladosporium sp. & Penicillium sp. \\
SE & $-0.1198^{\mathrm{ns}}$ & $-0.4512^{\mathrm{ns}}$ & $-0.6551^{*}$ & $-0.8069^{*}$ \\
\hline G & $-0.0555^{\mathrm{ns}}$ & $-0.4367^{\mathrm{ns}}$ & $-0.2991^{\mathrm{ns}}$ & $-0.5892^{*}$ \\
\hline FCG & $0.0447^{\mathrm{ns}}$ & $-0.4452^{* *}$ & $-0.4821^{* *}$ & $-0.6443^{*}$ \\
\hline ASG & $-0.1303^{\mathrm{ns}}$ & $0.2316^{\mathrm{ns}}$ & $0.4142^{\mathrm{ns}}$ & $0.4663^{* *}$ \\
\hline DSG & $0.0304^{\mathrm{ns}}$ & $0.2555^{\mathrm{ns}}$ & $0.2224^{\mathrm{ns}}$ & $0.4707^{* *}$ \\
\hline NSCD & $-0.1606^{\mathrm{ns}}$ & $-0.5075^{* *}$ & $-0.4905^{* *}$ & $-0.5653^{*}$ \\
\hline ASCD & $0.1755^{\mathrm{ns}}$ & $0.2236^{\mathrm{ns}}$ & $0.2031^{\mathrm{ns}}$ & $0.1346^{\mathrm{ns}}$ \\
\hline DSCD & $0.1068^{\mathrm{ns}}$ & $0.5243^{* *}$ & $0.4975^{* *}$ & $0.7009^{*}$ \\
\hline ESI & $-0.3318^{\mathrm{ns}}$ & $-0.1473^{\mathrm{ns}}$ & $-0.2732^{\mathrm{ns}}$ & $-0.3893^{\mathrm{ns}}$ \\
\hline EC & $-0.1017^{\mathrm{ns}}$ & $0.3945^{\mathrm{ns}}$ & $0.4666^{* *}$ & $0.6647^{*}$ \\
\hline
\end{tabular}

ns: not significant; * significant at $1 \%$ probability; ** significant at 5\% probability. SE: seedling emergence; G: standard germination; FCG: first count of germination; ASG: abnormal seedlings in the standard germination test; DSG: dead seeds in the standard germination test; NSCD: normal seedlings in the controlled deterioration test; ASCD: abnormal seedlings in the controlled deterioration test; DSCD: dead seeds in the controlled deterioration test; ESI: emergence speed index; EC: electrical conductivity. 
It was possible to verify the negative effect that these microorganisms can exert on the physiological quality of cucumber seeds, especially the fungus Penicillium sp., whose incidence was higher in the lower-vigor lots and which presented a negative correlation with SE and a positive correlation with dead seeds in the CD test.

\section{CONCLUSION}

The incidence of Penicillium sp. negatively influences the physiological performance of cucumber seeds evaluated by $\mathrm{SE}$ and by the results of the CD test.
ALMEIDA, A.S.; PINTO, J.F.; DEUNER, C.; VILLELA, F.A. Avaliação do potencial fisiológico de sementes de melancia. Revista da Faculdade de Zootecnia, Veterinária e Agronomia, Porto Alegre, v.17, n. 1, p.68-77, 2010.

ALVES, J.; BARBOSA, R.M.; COSTA, D.S.; SÁ, M.E. Condicionamento osmótico e desempenho fisiológico de sementes de rúcula. Biotemas, Florianópolis, v.25, n.1, p.171-176, 2012. http:// dx.doi.org/10.5007/2175-7925.2012v25n 1 p 171

AVINASH, T.S.; RAVISHANKAR RAI, V. Identification of diverse fungi related with selected Cucurbitaceae vegetables. International Journal of Agricultural Technology, Bangkok, v.9, n.7, p.1837-1848, 2013.

BOLIGON, A.A.; LÚCIO, A.D.; GARCIA, D.C. Emergência de plântulas de abóbora a partir da avaliação da qualidade das sementes. Ciência Rural, Santa Maria, v.40, n.11, p.2274-2281, 2010. http://dx.doi.org/10.1590/S0103-84782010001100005

BRASIL. Ministério da Agricultura e Reforma Agrária: Regras para Análise de Sementes. Brasília: Brasil DF. 2009. 365p.

BRAZ, M.R.S.; ROSSETTO, C.V. Correlação entre testes para avaliação da qualidade de sementes de girassol e emergência das plântulas em campo. Ciência Rural, Santa Maria, v.39, n.7, p.2004-2009, 2009. http://dx.doi.org/10.1590/ So $103-84782009005000146$

FARRAG, E.S.H.; MOHARAM, M.H.A. Pathogenic fungi transmitted through cucumber seeds and safely elimination by application of peppermint extract and oil. Notulae Scientia Biologicae, Cluj-Napoca, v.4, n.3, p.83-91, 2012. http://dx.doi.org/10.15835/nsb.4.3.7969

GOULART, L.S.; TILLMANN, M.A.A. Vigor de sementes de rúcula (Eruca sativa L.) pelo teste de deterioração controlada. Revista Brasileira de Sementes, Londrina, v.29, n.2, p.179-186, 2007. http://dx.doi.org/10.1590/SO101-31222007000200024

INTERNATIONAL SEED TESTING (ISTA). International rules for seed testing. Bassersdorf, Switzerland: International Seed Testing Association, 2012.

KIKUTI, A.L.P.; MARCOS FILHO, J. Testes de vigor em sementes de alface. Horticultura Brasileira, Brasília, v.30, n. 1, p.44-50, 2012.

KRZYZANOWSKI, F.C.; VIEIRA, R.D.; FRANÇA NETO, J.B. Vigor de sementes: conceitos e testes. Londrina: ABRATES, 1999. $218 \mathrm{p}$.
LIMA, B.P.; MARCOS FILHO, J. Procedimentos para condução de testes de vigor baseados na tolerância ao estresse térmico em sementes de pepino. Revista Brasileira de Sementes, Londrina, v.33, n.1, p.45-53, 2011 . http://dx.doi.org/10.1590/ S0101-31222011000100005

MACHADO, A.; CONCEIÇÃO, A.R. Programa Estatístico Winstat Sistema de Análise Estatístico para Windows. Versão 2.O. Pelotas: UFPel, 2002.

MAGUIRE, J.D. Speed of germination-aid in selection and evaluation for seedling emergence and vigor. Crop Science, Madson, v.2, p.176-177, 1962. http://dx.doi.org/10.2135/ cropsci $1962.0011183 \times 000200020033 x$

MALONE, P.F.V.A.; VILLELA, F.A.; MAUCH, C.R. Potencial fisiológico de sementes de mogango e desempenho das plantas no campo. Revista Brasileira de Sementes, Londrina, v.30, n.2, p.123-129, 2008. http://dx.doi.org/10.1590/SO101-31222008000200015

MAVI, K.; DEMIR, I. Controlled deterioration and accelerated aging tests predict relative seedling emergence potential of melon seed lots. Horticulture Science, Horndon, v.42, n.6, p.14311435, 2007.

MARCOS FILHO, J. Fisiologia de sementes de plantas cultivadas. Londrina: ABRATES, 2015.659p.

NAYYAR, B.G.; AKHUND, S.; AKRAM, A. A review: management of Alternaria and its mycotoxins in crops. International Journal of Advanced and Applied Sciences, Şahinbey, v.3, n.4, p.432-437, 2014.

NÓIA, N.R.C.; MAGNABOSCO, P.L.; LUDWIG, J. Qualidade sanitária de sementes de hortaliças. Tecnologia e Ciência Agropecuária, João Pessoa, v.8, n.2, p. 83-85, 2014.

RADKE, A.K.; REIS, B.B.; ALMEIDA, A.S.; MENEGHELLO, G.E.; TUNES, L.M.; VILLELA, F.A. Alternative methodologies to test seed vigor in lettuce. Enciclopédia Biosfera, Goiânia, v.10, n.19, p.94-101, 2014.

RUTZKE, C.F.J.; TAYLOR, A.G.; OBENDORF, R.L. Influence of aging, oxygen, and moisture on ethanol production from cabbage seeds. Journal of the American Society for Horticultural Science, Alexandria, v.133, n.1, p.158-164, 2008. https://doi.org/10.21273/ JASHS.133.1.158 
SOARES, V.N.; RODRIGUES, H.C.S.; GADOTTI, G.I.; MENEGHELLO, G.E.; VILLELA, F.A. Influence of fungi associated with watermelon seeds on physiological and health quality. Australian Journal of Crop Science, Queensland, v.10, n.6, p.852-856, 2016. https://doi.org/10.21475/ ajcs.2016.10.06.p7517

SOUZA, R.H.V.; VILLELA, F.A.; AUMONDE, T.Z. Methodologies based on seedling performance for vigor assessment of pumpkin seed. Journal of Seed Science, Londrina, v.35, n.3, p.374-380, 2013 . http://dx.doi.org/10.1590/ S2317-15372013000300015
TEKRONY, D.M. Precision is an essential component in seed vigour testing. Seed Science Technology, Zurich, v.3 1, p.435-447, 2003.

TORRES, S.B. Envelhecimento acelerado em sementes de pepino com e sem solução salina saturada. Horticultura Brasileira, Brasília, v.23, n.2, p.303-306, 2005. http://dx.doi.org/10.1590/ so $102-05362005000200028$

VIEIRA, J.F.; VILLELA, F.A.; LUCCA-FILHO, O.A.; CAMPELO, R.S. Physiological and phytosanitary potentials of coriander and radish seeds. Journal of Agriculture Science and Technology, Tehran, v.3, n.2, p.126-130, 2013. 